\title{
Concordantia Veteris et Novi Testamenti in the Mosaic of the Funerary Basilica of Via Dottor Consoli in Catania
}

\section{Katanya 'daki Via Dottor Consoli Mezar Bazilikası'nın Mozaiğinde Concordantia Veteris et Novi Testamenti}

\author{
Dominique Maria DI CARO*
}

(Received 26 January 2021, accepted after revision 23 August 2021)

\begin{abstract}
In 1930, it was discovered in the area of Via Dottor Consoli, in the northwestern sector of current urban centre of Catania, a cemetery complex used from the Hellenistic to the Byzantine era, by the Superintendence of Antiquities of Syracuse, under the direction of then Inspector G. Libertini. In that occasion, portions of the perimeter strip of a floor mosaic inside the basilica were brought to light, which during later excavation campaigns was completely excavated and detached in 1957 to be exhibited in the "salone di San Giorgio" of the Castello Ursino. Currently, it is kept in the storerooms of the ex-Manifattura Tabacchi (site of the future Regional Interdisciplinary Museum of Catania).

The mosaic of the basilica nave, dated to the middle of the sixth century AD, represents common secular themes on three registers: running felids, animals in combat and the marine scene with two men on a boat in front of a dragon with red coat dotted with white eyelets. In a panel there is a snake twisted around the trunk of a tree, in my opinion, to be identified with the Tree of knowledge mentioned by the sacred texts. In the Apocalypse, "the old serpent, which is called the Devil and Satan, the deceiver of the whole world" (Revelation 12, 9) becomes a great red dragon, who appears in the marine scene. An interpretative reading of the mosaic is proposed in the light of the rhetorical procedure of "significant inclusion" to enhance the unity and narrative continuity between the Old and New Testament.
\end{abstract}

Keywords: Sicily, Via Dottor Consoli of Catania, cemetery basilica, Late Antique mosaics.

Öz

1930 yılında Müfettiş G. Libertini yönetiminde Syracuse Eski Eserler Müfettişliği tarafindan Via Dottor Consoli Bölgesi'nde, Helenistik Dönem'den Bizans Dönemi'ne kadar kullanımda olan bir mezarlık kompleksi, Katanya'nın mevcut şehir merkezinin kuzeybatı kesiminde keşfedilmiştir. Bu vesileyle, bazilikanın içindeki mozaik zeminin dış şeridinin bazı kısımları gün ışığına çıkartılmıştır. Daha sonraki kazı çalışmaları sırasında ise tamamen kazılmış ve 1957'de Castello Ursino'da yer alan "Salone di San Giorgio"da sergilenmek üzere alınmış olup, eski Manifattura Tabacchi (şimdiki Katanya Bölgesel Disiplinlerarası Müzesi'nin bulunduğu yer) binasinda tutulmaktadir.

IS 6. yüzyılın ortasına tarihlenen Bazilika nefindeki mozaik, ü̧̧ bölmede genel dünyevi temaları temsil etmektedir. Bunlar koșu alanları, mücadele eden hayvanlar ile beyaz delikli gözlü ve kırmızı derili bir ejderhanın önündeki gemide iki adamın olduğu deniz sahnesidir. Bir panelde ise bir ağacın gövdesinde bükülmüş bir yllan bulunmaktadır ve kanımca bu, kutsal metinlerin bahsettiği bilgi ağactyla tanımlanabilir. İncil'in sonuncu faslında (Apocalypse) (12,9)"yaşl yılan ki iblis ve şeytan olarak bilinen, tüm dünyayı aldatan" olarak anılır ve deniz sahnesinde beliren büyük bir kırmızı ejderha haline gelir. Eski ve Yeni Ahit arasındaki birliği ve anlatı sürekliliğini arttırmak için retorik prosedürü ışığında mozaiğin yorumlayıcı bir okuması önerilmiştir.

Anahtar Kelimeler: Sicilya, Katanya Dottor Consoli Sokağı, mezarlık bazilikası, Geç Antik Mozaikleri.

\footnotetext{
* Dominique Maria DI CARO, Universidad Carlos III de Madrid (in international cotutela with the University of Calabria - UNICAL), Dpto. de Humanidades: Historia, Geografía y Arte. c/ Madrid, 126, 28903 Getafe, Madrid, Spain. (DD https://orcid.org/0000-0001-6030-9841. E-mail: arkeodomi89@gmail.com

I thank Marco Michele Mosca for the correction of the English translation of the text.
} 
Relevant for the knowledge of the first Christian community in Catania is the funerary epigraph of Iulia Florentina which, to date, constitutes the oldest Sicilian testimony regarding the experience of martyrdom (Rizzone 2008: 176177, 180-181). The newborn, prematurely dead after 18 months and 22 days in Hybla (today Paternò), was buried in Catania "near the tombs of martyrs", probably the patron saints Agatha and Euplius (Rizza 1964: 608-610), according to the widespread practice of ad sanctos burial. The epigraph is dated between 274 and 320, when Zoilo was Corrector of the province (Pincherle 1965: 554; Rizzo 2005: 37-38) and mentioned for the first time a presbyter (Rizzone 2008: 177). The tomb was found in 1730 in the farm of Don Ignazio Rizzari and more precisely in the central-southern part of the quarter bordered by the streets Androne, Tomaselli and Doctor Consoli (Soraci 2018: 26-29).

The area of archaeological interest, covered and partly demolished for the construction of modern buildings, is located in the northwest sector of today's historic centre of Catania, less than $1 \mathrm{~km}$ to northwest from the Roman amphitheater of Piazza Stesicoro, on the west side of Via Androne, at the intersection with Via Doctor Consoli. In ancient times the sacred complex was extramoenia, the limit of the Roman city was defined by the Amphitheater, while the Greek-Roman urban centre was developed on the hill of Montevergine.

The terraces of the hill, site of the Greek acropolis, in Roman times were occupied by a rich residential quarter with luxurious domus, served by aqueducts and paved roads, of which were found parts, especially in the courtyards of the exBenedictine Monastery in Piazza Dante and along Via Crociferi, which designed a regular orthogonal plant, which maintained the same characteristics at least until the fifth century (Privitera 2009: 59; Branciforti 2010: 139-183, 209-219, 240-247). As for the various burial areas, they "are laid out in relation to a road axis with north-south orientation that probably connected the acropolis to the Via Pompeia" (Trapani 1999: 78), coastal consular road that linked Messina to Syracuse.

In the area of Via Dottor Consoli, starting from 1930, structures related to a cemetery complex (various necropolis, a tricora, a basilica, mosaics and funerary epigraphs), in use from the Hellenistic to the Byzantine era, were brought to light by the Superintendence of Antiquities of Syracuse, under the direction of G. Libertini, professor of archaeology and Honorary Inspector of the Superintendence of Syracuse, in collaboration with G. Rizza, who took over from 1954, becoming Inspector (Trapani 1999: 77 and notes 2, 3; 78). In 1930 Libertini discovered portions of the perimeter strip of a floor mosaic inside the basilica (Trapani 1999: 77 and note 3; 83 and note 22), which in the course of subsequent excavation campaigns was completely brought to light and together with it also the entire mosaic (Rizza 1955: 1-11), detached in 1957 to be exhibited in the "salone di San Giorgio" of the Castello Ursino (Trapani 1999: 728 and note 4, 726). Currently, it is kept in the storerooms of the Ex-Manifattura Tabacchi (site of the Regional Interdisciplinary Museum of Catania) ${ }^{1}$.

In the years 1950-51, 1953-57, in particular in the area near Via Androne, Via Nino Martoglio and Via Sant'Euplio, in connection with the upgrading of the

1 I would like to take this opportunity to thank Dr Gioconda Lamagna, the building manager, who, during a recent conversation, told me that the mosaic in question was originally exhibited in a room of the Civic Museum of Castello Ursino, but following the mosaic restoration, the various panels were packed and deposited in the storerooms of the ex-Manifattura Tabacchi. While waiting for an appropriate exhibition project and museum opening, unfortunately, at the moment it is not possible to view it. 
Figure 1

Catania. Plan of the funerary complex in via Dottor Consoli (Sgarlata 2017: 54 fig. 7). road surface and the construction of some buildings, numerous investigations were carried out, while parts of necropolis with Christian burials and funeral enclosures were found (Libertini 1956: 170-189). Other sections connected to the necropolis of via Dottor Consoli were identified in via Plebiscito / corner via Antico Corso, via S. Euplio / la Rinascente department store and later, in 1968, in the area of via Orto S. Clemente (Rizza 1987: 157-166).

Between 1994 and 1999 other late antiquity necropolis were found under Palazzo Tezzano and in the ex-monastery of Santa Caterina, recently to the east of the Amphitheatre, in the area of Palazzo San Giuliano and Teatro Machiavelli (Rizzo 2005: 154-155).

The funeral complex (Fig. 1) included a basilica dated to the sixth century, to the southwest of it, near the apse, a small tricora with the function of martyrium of the fourth century and large funeral areas within communicating fence walls of various periods of use (Libertini 1956: 170-189; Rizza 1964: 593 - 612). The basilica, oriented to the east, had three naves and an apse with inside an annular row of formae, a synthronon with masonry benches to high espalier and episcopal chair in the centre, according to a North-African recurrent typology (Trapani 1999: 82 and note 15).

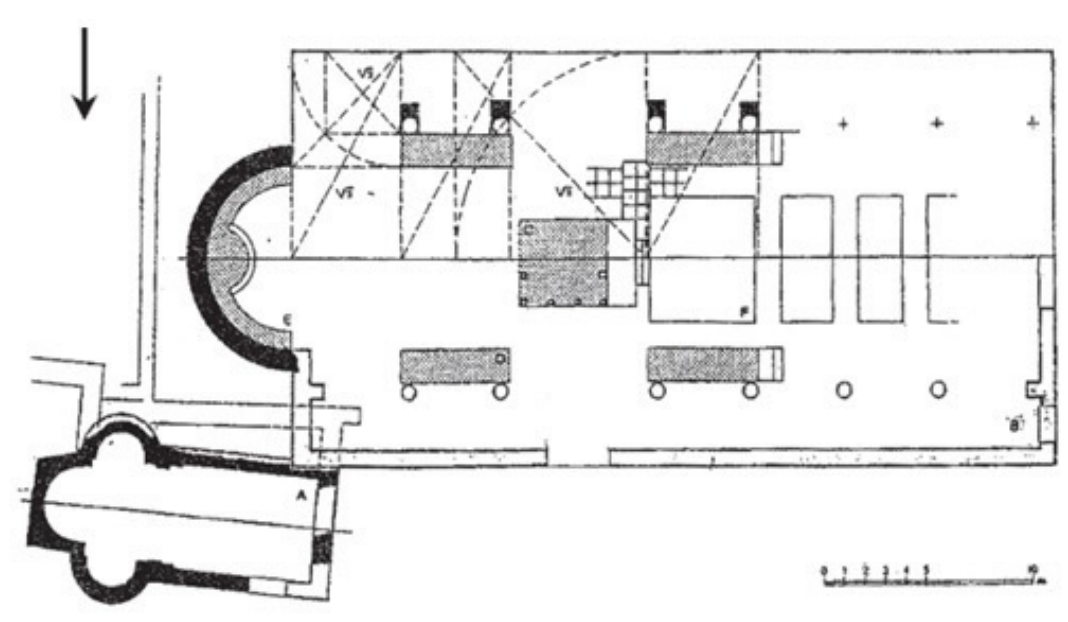

The nave, covered with polychrome mosaic, measured $\mathrm{m} 11.30 \times 42 \mathrm{~m}$, in the centre there was a lava stone altar, of which few fragments remain and it was surrounded by transennas and raised with the addition of a podium with two steps and floor decorated with marble crustae, with a tomb beneath (Trapani 1999: 83). The basilica lost its function as a martyrium at a later stage, as attested by the displacement of the floor level of the presbyteral area, totally damaged (Trapani 1999: 83).

For a long time, it had to be a pilgrimage destination, probably under the table of the altar, bodies' remains of Saint Agatha and Saint Euplus were placed, originally kept in the nearby tricora. It is a certain fact that the sepulchral complex was dedicated to the cult of martyrs and the above-mentioned epigraph by Iulia Florentina (CIL X, 7112) is a clear proof (Rizza 1964: 608-610), in which the expression "pro foribus martXPorum" suggests that Iulia was buried in a privileged area connected to the martyral tombs, the remains of the child were found in the garden of Villa Rizzari, which is located in the central-southern part of the quarter bordered by today's streets Androne, Tomaselli and Doctor Consoli and therefore close to our basilica (Rizza 1964: 595). 
The polychrome mosaic, dated to the middle of the VI century (Pautasso 2015: 726, with previous bibliography: Rizza 1953; 1954; 1955; 1964; Trapani 1999), covered the entire floor of the basilica: stretched from the beginning of the apse until, almost entirely, the central nave for about $\mathrm{m} .31$, except for the base of the altar (Rizza 1964: 593-612; Trapani 1999: 83-84; Pautasso 2015: 730 note 7. Pautasso reported the recent studies of A. Tempio, who identified with greater precision the area of discovery of the epigraph, confirming the hypothesis of Rizza).

The mosaic, as it is visible from a 50s photo, published from Pautasso in 2015 (Fig. 2), is composed of more figurative units, delimited from a wide perimetral band. The band (Fig. 3) is decorated by a double strapwork of alternating squares and circles interlooped tangentially by a polychrome cords with eyelets (Décor I: 81d), containing various species of birds drawn in profile, stepping toward different directions.

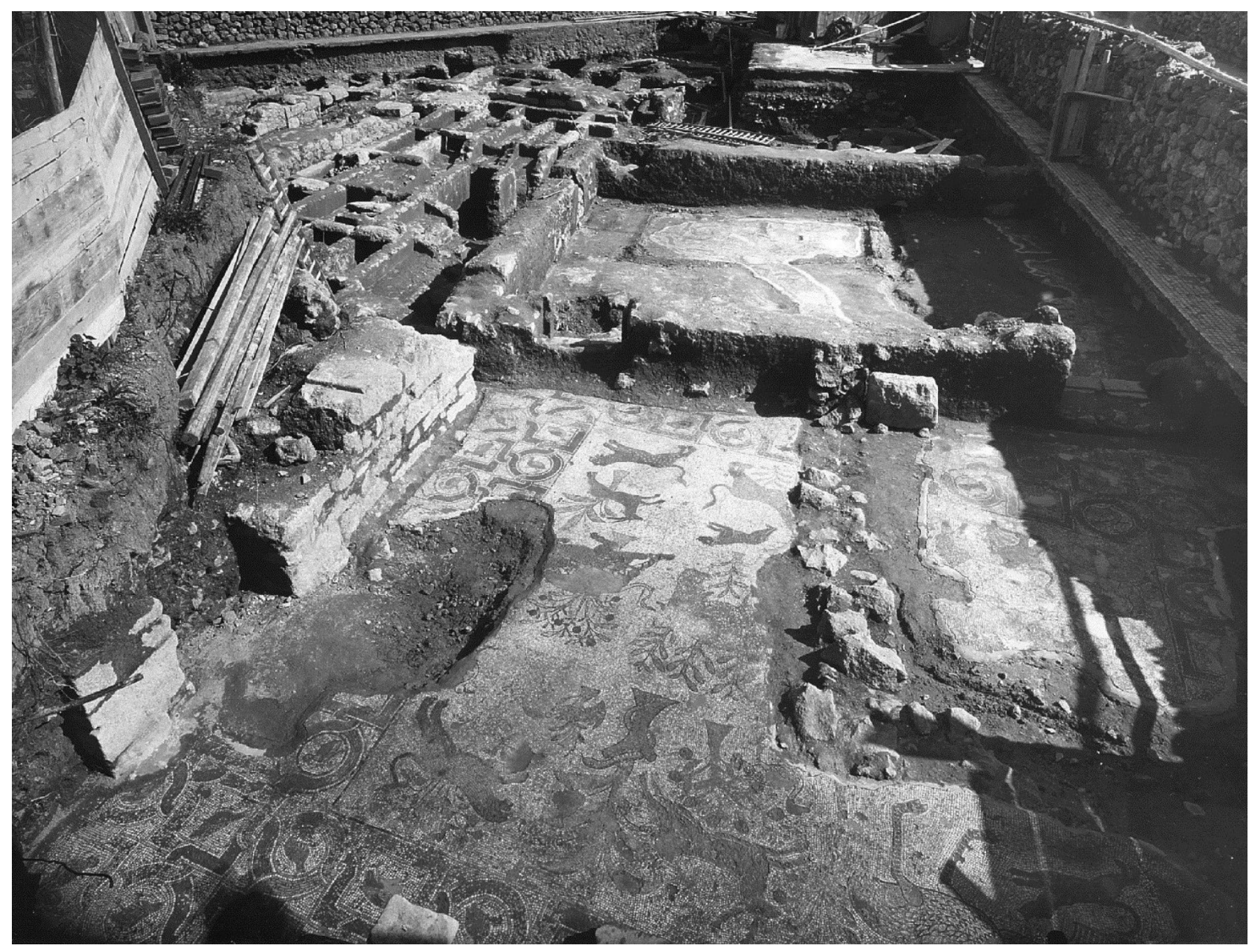

Two figurative units can be identified in the mosaic field, the first $(5,68 \times 5,10$ $\mathrm{m})$ one better preserved, is divided into three registers: at the bottom right there is the scene with felids running in an arid landscape with sparse shrubs, we can distinguish a cheetah and a deer going to opposite directions (Fig. 3); the second register shows fighting animals and thick bushes in the background, you can see a tiger biting a deer. The last register is richer: on the right side, on the sides of a luxuriant tree with a snake twisted around the trunk, there are a cheetah and a
Figure 2

Catania. Funerary basilica in via Dottor Consoli, mosaic of the central nave (archeological excavations of Rizza, years 1953-54, 1956-57) (Pautasso 2015: 724 fig. 3). 
Figure 3

Catania. Funerary basilica in via Dottor Consoli, detail of the mosaic in the central nave (Pautasso 2015: 724 fig. 4).

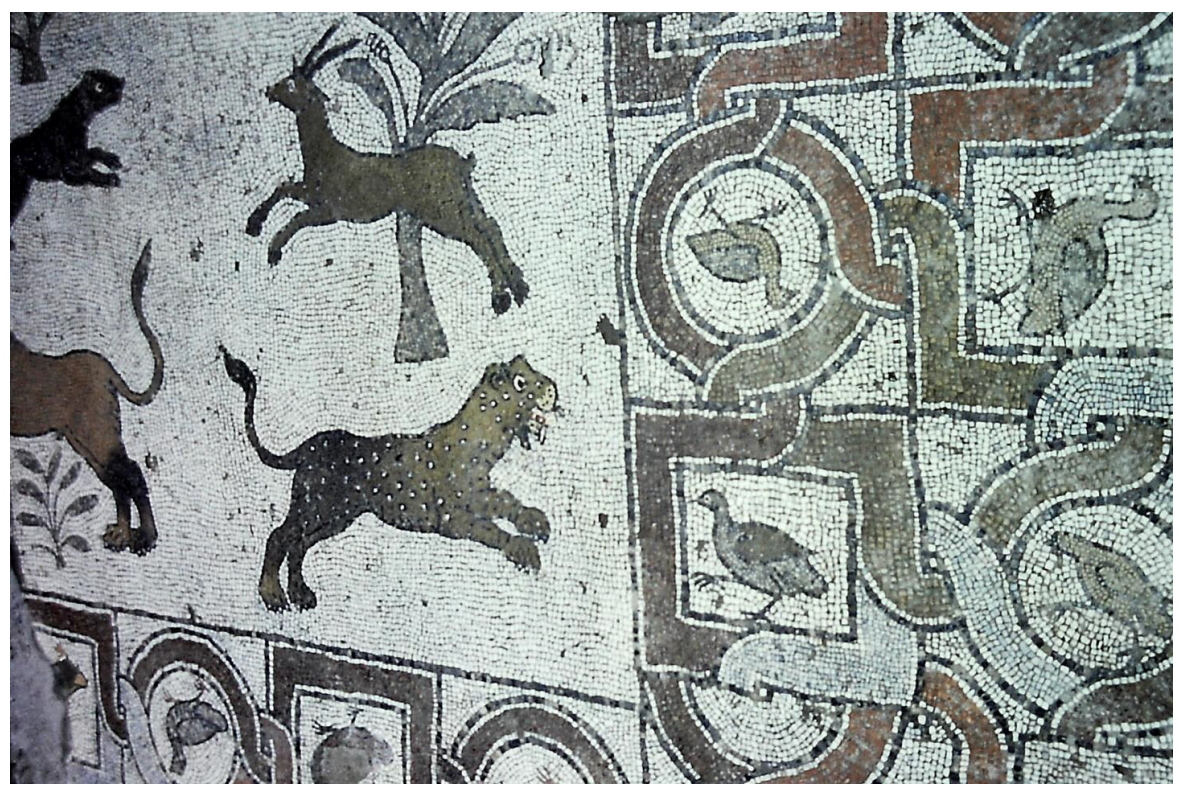

deer going to the left, in the background various shrubs and small birds; finally, in the left part there are a big bird with high and robust legs, walking towards the left, probably an ostrich, in front of which a dog stands on the lower legs, the remaining part is incomplete.

A second unit $(5,68 \times 10 \mathrm{~m})$, framed by the same band, but more incomplete, represents a marine scene (Fig. 4): on a small boat there are two men, of which one naked sitting, probably an erote, in the act of rowing and one standing, of greater dimensions, with short tunic and long pole. In front of the two figures, there is a sea monster with a big dragon head and a red coat dotted with white eyelets and on top of it a large polychrome fish. The background is blue, while the movement of the waves is represented by undulating rows of white tesserae. The religious theme of navigatio vitae goes beyond the boundaries of the Christian iconographic repertoire of the origins, starting from the popular profane art, which then changes its meaning: the image of the sea, symbol of cosmic chaos, of the unknown and of the evil, in the New Testament it will become the surface on which Christ walks, among his followers he will choose fishermen and the figure of fish will acquire a deep Christological significance.

Figure 4

Catania. Funerary basilica in via Dottor Consoli, detail of the mosaic in the central nave (Pautasso 2015: 724 fig. 5).

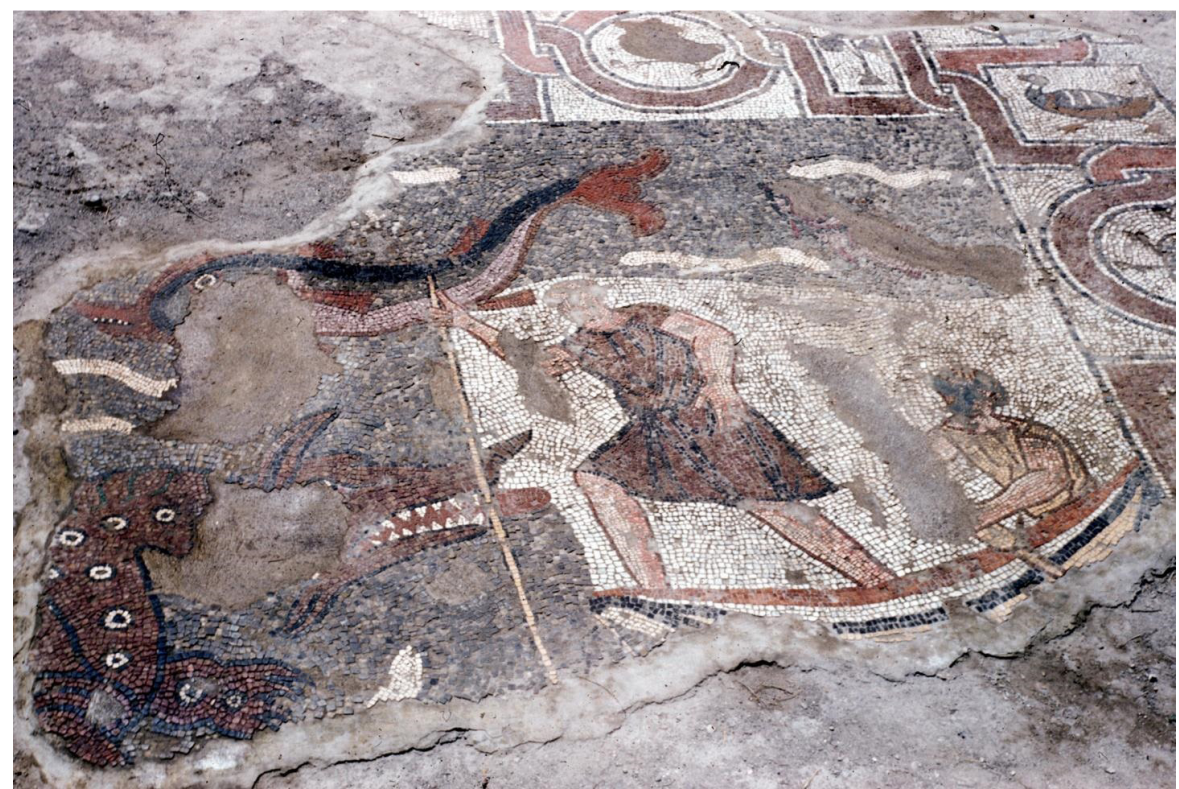


In addition to the rural and marine scenes, Rizza describes two other panels also delimited by the same frame, one of which with scenes of pastoral life and hunting and the other, particularly incomplete, near the entrance of the basilica, with the representation of life in the fields (Rizza 1955: 5-7). The first one (5,68 x 3,48 m) has a central composition, where a young man with a short tunic sits on a rock behind which emerges a shrub on which he hung his mantle on a shrub, represented in the act of playing a horn (Rizza 1955: figs. 11, 7). At his feet two sheep and a goat lie, while a dog turns its head towards him. On the right of the group is represented a cow suckling the calf and on the left a man on a horse, in the act of striking with a spear an animal now no longer visible; finally in the corner two dogs on the sides of a tree that probably had to be represented symmetrically even in the lost right corner (Rizza 1955: 5-6). The central group refers - as the scholar suggests - to the iconographic model of Orpheus that enchants fairs (Rizza 1955: 8-9). The pagan image of the singer, widespread in the Christian tombs of the first centuries, is assimilated to that one of Christ the Good Shepherd who "enchants" men with his word (John 10: 1-18). The first panel for those who entered in the basilica represented probably the harvest, since one of the two figures that are identified carried a bundle of wheat ears (Rizza 1955: 6-7).

The mosaic production of the Sicilian places of cult is essentially aniconic, probably to be interpreted as a form of caution in anti-pagan function.

The mosaics of the funerary basilicas of Contrada San Miceli in Salemi (TP) (Lesnes - Younker 2018), of Caucana (Pelagatti - Di Stefano 1999: 21-30 figs. 19-22) and Contrada Pirrera (Pelagatti - Di Stefano 1999: 36-38; Di Stefano 2000: 31-36; Di Stefano - Ventura 2012: 155-165) in the Santa Croce Camerina territory $(\mathrm{RG})$ present zoomorphic and vegetal motifs within reticulates, as in the band of the mosaic of Catania, alluding to the garden of Paradise and the pacification of animals (Isaiah 11: 6-9 and 65: 25). The mosaic of Catania is an exception, along with that one of the bema in the funerary basilica of Nunziata di Mascali (late V - middle VI century) (Buda 2015), always in the territory of Catania, because attributable to a mature phase of Christianity. The mosaic of Mascali (Buda - Taormina 2014: 209-218) presented in the centre a kantharos or a water source (unfortunately the central part is extremely full of gaps) and symmetrically on the sides a couple of deer, tufts of acanthus leaves and peacocks, represented in reference to the pacification of the Messianic era, prophesied by Isaiah (Isaiah 11: 6-9 and 65:25). The deer and peacocks allude to the triumph of the good over the evil, both in fact are enemies of the snake (= sin, temptation). The latter is represented in the mosaic of via Doctor Consoli twisted around the tree trunk, which according to my interpretative reading could be "The Tree of Knowledge" mentioned in the sacred texts.

The tree, which is morphologically a vertical axis, implies that it represents the relationship between three levels: the subterranean, the terrestrial and celestial world recalling a spiritual evolutionary process. While in the pagan world the image of the tree has a positive value: the apple tree given as gift by Gaea to Hera, kept in the Garden of the Hesperides, produced golden fruits that bestowed immortality; in the book of Genesis, in the centre of Paradise there was the Poisonous Tree of "knowledge of good and evil" from which it was forbidden to eat (Genesis 2: 9; 16), as well as the Tree of life that God made sprout in the middle of the Garden of Eden (Genesis 2: 9), symbol of immortality.

The duality of the tree will lead man to transgress and lose to the eternal life (Genesis 3: 22). In the mosaic panel of the cemetery church in via Dottor 
Consoli the Tree is represented leafy with a "triumphant" snake twisted around the trunk, narrow is the visual reference to the snake of Asclepius wrapped around a stick, however symbol of medicine and salvation. The ambivalence of the snake is found in the New Testament tradition (in John 3: 14 and following verses: the copper serpent that Moses raised in the desert is a prefiguration of the resurrection of Christ), but the negative connotation, in which it is an image of perfidy, destruction and evil, reappears with emphasis in the Apocalypse, where "the ancient serpent, the one we call the devil and satan and who seduces the whole earth" (Revelation 12: 9) becomes a great red dragon.

It is not a coincidence that "the beast of the sea" appears in another scene of the mosaic in a marine context, suggesting therefore the hypothesis that it may refer to the verses of Revelation 12: 17-18, which narrate that "The dragon was furious [...] and went off to fight against the rest of her descendants, all those who obey God's commandments and are faithful to the truth revealed by Jesus. And the dragon stood[a] on the seashore"; in verse 13: 1 "Then I saw a beast coming up out of the sea." and again in verse 17: 8 "That beast was once alive, but lives no longer; it is about to come up from the abyss and will go off to be destroyed". If the interpretative reading is correct, it appears plausible the use of the rhetorical procedure of "significant inclusion" to enhance the unity and narrative continuity between the Old and New Testaments, the last book closes the loop: the end joins to the beginning and the latter is a prophetic prefiguration of salvation history.

The Edenic dimension narrated in Genesis is found at the end of times, John writes "and flowing down the middle of the city's street. On each side of the river was the tree of life, which bears fruit twelve times a year, once each month; and its leaves are for the healing of the nations" (Revelation 22: 2). Thus the Old Testament serpent constitutes the archetype of the dragon, its mythological transposition, which both are malefic figures; another present element in our mosaic is the sea with floating waves, also in the biblical texts personification of the evil that will disappear in the Johannine Revelation (Revelation 21: 1).

Returning to the mosaic of the Nunziata, that of the nave (Fig. 5), better preserved, represents the marine bestiary whose subjects (fishes, octopus, cuttlefishes, shells) are arranged to form a double square plot, overlapped and with offset lines. The field is bordered by a band of circles interlaced by red and green cords with eyelets (Décor I: 69f) delimited by rows of black and white tesserae (in the mosaic of the bema there is the simple variant with a band of only circles, Décor I: $68 \mathrm{~b}$ ), the circles containing birds and marine animals facing inwards and there are in the corners four small kantharoi. In the resulting spaces, there are tangent semicircles at the edges of the band, with contrasting colours.

The motif is similar to that one of the mosaic in via Dottor Consoli (Fig. 3), where the circles are alternately interlaced with straight squares. The animals in the band are all birds, considered "pure animals" by Genesis (Genesis 7: 8), symbol of the soul and its elevation to God (Massara 2007: 169). The birds are represented in numerous Christian basilicas contexts, mostly with funerary function. The choice does not appear random or simply decorative, it is influenced by the North African funerary mosaic tradition which represented, within dense geometric reticulates, the birds in the mosaics that covered the tombs probably to symbolize the souls of the dead in Paradise or in general the Creation (Massara 2007: 224-230).

Thanks to its geographical position and its political-religious role, even in the Byzantine era, Catania was a centre of meeting and reviewing of ideological, cultural and artistic international models, perfectly fitting into a Mediterranean 


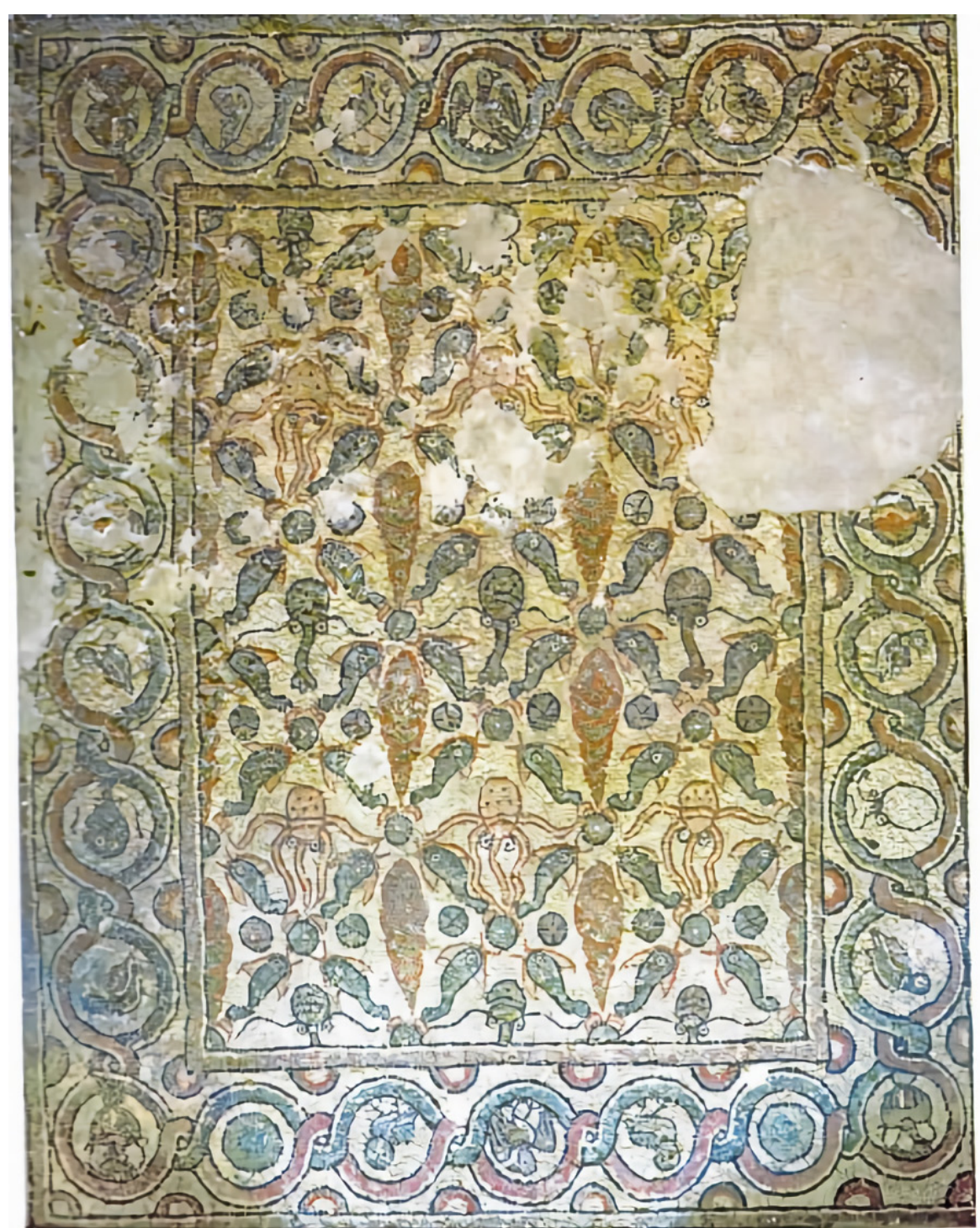

koine, of which the mosaic art of Catania is a clear expression. The mosaics of the basilica in via Dottor Consoli in fact are aligned with the mosaic productions of the sixth century permeated by African and Middle Eastern elements. In the first case the main comparisons, selected by Bonacasa Carra, are found in Tripolitania and Cyrenaica (today's Libya), in the latter the central basilica of Cyrene and the eastern basilica of Gasr-el-Lebia present similarities both in the planimetric structure and in the mosaic composition (Carra Bonacasa 2019: 25-28). Alongside the North African influences, new oriental trends emerged, coming mainly from the Greek and Syrian-Palestinian areas. In the figurative scenes of running animals and hunting there are stringent comparisons with the Antiochene mosaics (House of Ktisis, Dumbarton Oaks Hunt, Worcester Hunt) dating back to the first twenty-five years of the sixth century (Rizza 1955: 7-8); while the motif of the frame with circles interlaced with squares recurs in the Greek-Oriental mosaics of the fifth and sixth centuries (mosaics of Astypalaia and Aphrodisias of Caria) (Buda-Taormina 2014: 211) and in the JordanianPalestinian (Al-Quwaysmah near Amman, mosaic of Orpheus of Jerusalem, Umm Jerar) datable to the full sixth century (Rizza 1955: 8-10; Buda-Taormina 2014: 213), whose archetype was found in Cyprus, in the mosaic of the Basilica of Agia Kyriaki Chrysopolitissa in Paphos, dated to the fourth century (Carra Bonacasa 2019: 27 note 3).
Figure 5

Catania. Funerary basilica in Nunziata of Mascali, mosaic of the central nave (Buda 2015: 50 fig. 44). 
In our mosaic the typical characteristics of Byzantine art can be seen both on the executive level since the mosaic covered the floor entirely and the craftsman employed smaller tesserae for the rendering of faces and details to obtain a pictorial definition and on a purely stylistic-compositional level. The last level is identified by the decorative motifs of the frame that act as dividing elements modulating the mosaic into several registers, the use of the marked contour line of dark-gray colour that draws the anatomical details and detaches the figures from the background, the chromatic richness used to obtain "chromatic accords" that soften and blend the contrasts for a unitary composition (Rizza 1955: 4-6), the absence of spatial perspective and naturalistic proportions (Rizza 1955: 10: the main characters have larger size than the secondary ones as in the case of the sitting shepherd figure $1.25 \mathrm{~m}$ high, compared to that of the horseman 0.90 $0.95 \mathrm{~m}$ high) together with a dematerialization of the figures that appear floating in space in the absence of a support plane, order to compose a "continuous representation", reproducing different subsequent episodes of the same "story".

The panel with a marine scene near the entrance of the basilica, in the light of the available archaeological documentation, should be included in the "exceptional" group of Christian mosaic representations, because it is a unicum in Sicily, since it represents a New Testament theme, as proposed in this discussion, or an Old Testament theme. Bonacasa proposes to identify the scene with the biblical episode in which Jonah is thrown into the sea, associating the dragon with the water monster that swallowed and spewed the prophet (Carra Bonacasa 2019: 28). The interpretation does not appear plausible because it is not represented the usual storm scene during which Jonah is thrown by the sailors into the monster's jaws, and on the boat together with the main character, of higher size, positioned at the stern and represented in the act of bringing in front of himself the oar, there is only a seated naked man, from whom no action is predictable and recognizable. Moreover, the red dragon is different from the classic iconographic type of ketos, a cold-colored marine creature with a snake-like or a fish body with fins/wings, a crocodile head with an elongated snout, a long and twisted neck, front legs and a tail wrapped in spirals that recalls the classic hippocampus of marine thiasos.

The prophet is frequently represented in the paintings of the necropolis of Syracuse and in particular in those ones of the Ex Vigna Cassia, in which in a loculus of unknown location in the ancient nucleus of St. Diego, the scholar Germanà reported the presence of a "fragmentary mosaic with the representation of a ship suspended over the waters, on which there is a robust sailor probably naked trying to keep himself in balance while he is hurling Jonah, also represented naked, into the sea. On the right, near the ship, we can see the ketos, whose body is fantastically decorated with fins and the final part of the body with serpentiform appearance, heavy legs, curved neck and wide open jaws in a head turned back" (Germanà 2018: 73). The known mosaic examples are very few, evidently the theme of the story of Jonah in mosaic production was not particularly successful (it was more popular in early Christian painting and sarcophagi) and it was probably preferred to represent the entire trilogy rather than a single episode. It is found in the mosaic floor of the eastern span of the Teodorian mosaic located in the southern hall of the basilica of Aquileia (second decade of the fourth century), and in the panels, very fragmentary, of the dome of the roman villa of Centcelles, near Tarragona (fourth century). At the moment it seems useless to dwell on possible comparisons, the discovery of Syracuse mosaic and direct studies will provide scientifically solid solutions. 
To conclude, regarding to the sea monster, although there are different iconographic variants, only in the Middle Ages it was assimilated to the dragon (most common is the version that portrays it as piscem grandem), therefore this identification hypothesis should be excluded; it's also unlikely that it could portray the Leviathan, mentioned in the Book of Psalms (74: 14; 104: 26), in that one of Isaiah (27:1) and in that one of Job (40:25-32; 41:1-26), which is described as a "tortuous serpent" of the sea, therefore without legs, with brutal ferocity so that "No one is fierce enough to rouse it" (Job 41: 10). The advanced typological interpretation observes dialectical allegorical and compositional equivalences on the basis of which the snake in the panel of the first span is the archetype of the red dragon, mentioned in the Apocalypse, which lies in the panel of the third span (see supra), "demonstrating" visually - as Eusebius of Caesarea did theoretically in the apologetic work "Demonstratio Evangelica" the continuity and concordance between the Old and New Testaments, forming the biblical theology.

The question of testamentary dualism was a prerogative of exegetes since the time of Philo of Alexandria (about $20 \mathrm{BC}$ - about $45 \mathrm{AD}$ ) and was defined by the calabrian abbot Gioacchino da Fiore (1130-1202 AD), who wrote Concordia Novi ac Veteris Testamenti, based on the hermeneutic system of the patristic and medieval tradition, which reviews, through the allegoricus intellectus (allegorical-spiritual reading) and the intelligentia typica (historical-typological reading), a series of variants: historical, moral, tropological, contemplative and anagogical, which in correlation with each other converge to the notion of "concordantia" (Mottu 1983: 70-102). This doctrinal work involved figurative art and in particular the mosaic cycles of Western churches for their pedagogical function of Biblia pauperum: the mosaic of Via Dottor Consoli in Catania - in the light of these reflections - might have been one of the earliest examples. 


\section{Bibliography - Kaynaklar}

Branciforti 2010

Buda 2015

Buda -Taormina 2014

Carra Bonacasa 2019

Décor I

Di Stefano - Ventura 2012

Germanà 2018

Libertini 1956

Massara 2007

Mottu 1983

Pautasso 2015

Pelagatti - Di Stefano 1999

Pincherle 1965

Privitera 2009

Rizza 1953

Rizza 1954

Rizza 1987

Rizzo 2005

Rizzone 2008

Sgarlata 2017

Trapani 1999
M. G. Branciforti, "Da Katane a Catina”, M. G. Branciforti - V. La Rosa (eds.), Tra lava e mare: contribuiti all'archaiologhia di Catania, Catania, 135-258.

G. Buda (ed.), La Nunziatella sopra Mascali, Palermo.

G. Buda - A. Taormina, "Basilica paleocristiana con mosaici policromi a Nunziata (CT) nell'area ionico-etnea", C. Angelelli (ed.), Colloquio Atti del XIX Colloquio dell'Associazione Italiana per lo Studio e la Conservazione del Mosaico, Tivoli, 209-218.

R. M. Carra Bonacasa, "Il mosaico pavimentale della basilica di Via Dottor Consoli a Catania. Appunti per una lettura", Sicilia Antiqua, International Journal of Archaeology, Studi in memoria di Giovanni Rizza XVI, PisaRoma, 23-35.

C. Balmelle - M. Blanchard-Lemée - J. Christophe - J.-P. Darmon - A.-M. Guimier Sorbets - H. Lavagne - R. Prudhomme - H. Stern, Le Décor géométrique de la mosaïque romaine I, Paris, 1985.

G. Di Stefano - G. Ventura, "Gli ambienti collaterali nelle chiese siciliane. Il caso della basilica della Pirrera. Scavi dell'Università della Calabria (2010). Notizie preliminary", Atti del X Congresso Nazionale di Archeologia Cristiana, Cosenza, 155-165.

G. Germanà, "Riferimenti biblici nelle pitture delle catacombe di Siracusa", A. Giudice - G. Rinaldi (eds.), Realia Christianorum II, La Bibbia e la sua esegesi, Atti del Convegno, Bologna, 59-89.

G. Libertini, "Catania. Necropoli romana e avanzi bizantini nella via Dottor Consoli”, NSc VIII 10, 170-189.

F. P. Massara, "I mosaici paleocristiani e bizantini della Sicilia: osservazioni iconografiche”, Sulle tracce del primo cristianesimo in Sicilia e in Tunisia, Regione siciliana, 165-171.

H. Mottu, La manifestazione dello Spirito secondo Gioacchino da Fiore. Ermeneutica e teologia della storia secondo il «Trattato dei quattro Vangeli», Casale Monteferrato.

A. Pautasso, "Giovanni Rizza e l'archeologia urbana a Catania nella seconda metà del XX secolo", F. Nicoletti (ed.), Catania Antica, Nuove prospettive di ricerca, Palermo, 721-739.

P. Pelagatti - G. Di Stefano, Kaukana. Il chorion bizantino, Palermo.

A. Pincherle, "Sulle origini del cristianesimo in Sicilia", Kokalos X-XI, (1964-1965), 547-563.

S. Privitera, "Lo sviluppo urbano di Catania dalla fondazione dell'apoikia alla fine del V secolo d.C.”, L. Scalisi (ed.), Catania, L'identità urbana dall'antichità al Settecento, Catania, 37-71.

G. Rizza, "Scoperta di un mosaico a Catania", FA 8, n. 5104, 378.

G. Rizza, "I mosaici di via Dottor Consoli", Catania, Rivista del Comune di Catania 3, luglio-settembre, serie II, anno II, 55-63.

G. Rizza, "Storia della ricerca archeologica", Bibliografia topografica della colonizzazione greca in Italia e nelle Isole tirreniche, vol. V, Pisa-Roma, 157-166.

F. P. Rizzo, Sicilia cristiana dal I al IV secolo, vol. I, Roma.

V. Rizzone, "La più antica comunità cristiana di Catania attraverso i documenti epigrafici (secoli IV-V)", Agata santa. Storia, arte, devozione, Firenze-Milano, 175-189.

M. Sgarlata, "Sicilia cristiana. Un quadro di sintesi delle dinamiche di trasformazione delle aree urbane e rurali orientali”, MitChrA 23, 39-62.

F. Trapani, "Il complesso cristiano extramoenia di via Dottor Consoli a Catania", ArchStorSicOr 95, 77-124. 
